\title{
Pengaruh Penggunaan Tepung Ampas Kecap pada Pakan Ayam Petelur Tua terhadap Kualitas Interior Telur dan Income Over Feed Cost (IOFC)
}

\author{
Dietary Inclusion of Soybean Sauce by product on Interior Eggs Quality of Laying Hens after \\ Peak Production and Income Over Feed Cost (IOFC)
}

\section{D.U. Kusumaningrum, L. D. Mahfudz, dan D. Sunarti}

Fakultas Peternakan dan Pertanian, Universitas Diponegoro, Semarang

Kampus drh. R. Soedjono Koesoemowardojo Tembalang Semarang 50275

Email : dinarutami72@yahoo.com

\begin{abstract}
Soybean sauce by product as an alternative of animal feed. This research was aimed to examined the soybean sauce by product in the diet of laying hens after peak production on eggs interior quality. Experimental material were 200 birds laying hens strain Lohmann Brown at 80 weeks old. The experimental design was used completely randomized design (CRD) with 4 treatments and 5 replications and each unit contains 10 birds. Treatments were dietary soybean sauce by product as follows T0 (control diet $0 \%), \mathrm{T} 1(10 \%), \mathrm{T} 2(12.5 \%)$ and T3 (15\%). Data were analyzed using analysis of variance. Research result showed that soybean sauce by product did not effected $(\mathrm{P}>0.05)$ to the egg yolk, index of egg yolk and egg yolk weight. The conclusion of this examination is soybean sauce by product was not able to improve interior egg quality.
\end{abstract}

Key words: soybean sauce by product, interior egg quality, laying hens

\begin{abstract}
ABSTRAK
Ampas kecap merupakan limbah dari proses pembuatan kecap berbahan dasar kedelai yang mengalami proses fermentasi dan dapat digunakan sebagai pakan alternatif untuk ternak. Penelitian ini bertujuan untuk mengkaji pengaruh penggunaan tepung ampas kecap dengan level 10\%, 12,5\% dan 15\% pada pakan terhadap kualitas interior telur. Materi yang digunakan adalah ayam petelur strain Lohman Brown sebanyak 200 ekor umur 80 minggu. Rancangan percobaan yang digunakan yaitu Rancangan Acak Lengkap dan diulang 5 kali dan setiap ulangan berisi 10 ekor. Perlakuan adalah 4 level tepung ampas kecap yaitu T0 (pakan kontrol tanpa tepung ampas kecap), T1 (pakan dengan 10\% tepung ampas kecap), T2 (pakan dengan 12,5\% tepung ampas kecap) dan T3 (pakan dengan 15\% tepung ampas kecap). Parameter yang diamati adalah Data dianalisis dengan menggunakan analisis variansi. Hasil penelitian menunjukkan bahwa tepung ampas kecap tidak berpengaruh nyata $(\mathrm{P}>0,05)$ terhadap warna kuning telur, indeks kuning telur dan bobot kuning telur. Kesimpulan dari penelitian ini yaitu tepung ampas kecap pada taraf $15 \%$ belum mampu memperbaiki kualitas telur secara interior.
\end{abstract}

Kata kunci : ampas kecap, kualitas interior telur, ayam petelur tua

\section{PENDAHULUAN}

Telur memiliki peran penting dalam kehidupan sehari-hari di kalangan masyarakat Indonesia. Hal ini disebabkan karena harga telur yang relatif murah sehingga dapat dijangkau oleh masyarakat, selain itu semakin timbulnya kesadaran masyarakat akan pentingnya gizi terutama protein hewani. Telur merupakan bahan makanan yang bernilai gizi tinggi, yang dibutuhkan oleh tubuh manusia. Telur mengandung protein tinggi, selain itu telur juga merupakan sumber zat besi, mineral dan vitamin sehingga telur dapat dikonsumsi oleh manusia pada segala umur.

Telur yang baik pasti juga memiliki kualitas yang baik, dilihat dari interior maupun eksterior. Kualitas telur merupakan salah satu faktor yang menentukan tingkat kesukaan konsumen. Kualitas telur dapat dipengaruhi oleh beberapa faktor 
diantaranya yaitu penyusutan bobot telur, keadaan rongga udara, keadaan kuning dan putih telur, bentuk dan warna kuning telur serta tingkat kebersihan cangkang telur (Sauda et al., 2012). Kualitas interior telur juga dipengaruhi oleh faktor umur ternak, suhu lingkungan dan pakan yang dikonsumsi oleh ternak (Yuliansyah, 2007).

Dalam usaha peternakan ayam petelur, biaya pakan merupakan komponen biaya yang paling tinggi yaitu sekitar 70$80 \%$. Untuk itu, perlu diusahakan pemberian bahan pakan alternatif yang murah, mudah didapat, tidak bersaing dengan manusia dan memiliki kualitas yang baik untuk dijadikan bahan pakan ayam petelur.

Ampas kecap merupakan limbah dari proses pembuatan kecap berbahan dasar kedelai yang mengalami proses fermentasi, penyaringan dan pengepresan (Sukarini, 2004). Ampas kecap memiliki kandungan protein kasar 27\%, abu 19\%, kalsium $0,39 \%$, fosfor $0,33 \%$, lemak kasar $12 \%$ dan serat kasar $11 \%$ (Herdiana et al., 2014). Ampas kecap dengan kadar protein, isoflavon dan mineral seperti diatas, apabila digunakan sebagai bahan pakan untuk menyusun ransum diharapkan dapat mempertahankan kualitas interior telur. Isoflavon merupakan senyawa aditif yang berfungsi untuk meningkatkan produktivitas dan kualitas produksi ayam petelur. Isoflavon berfungsi sebagai pitoestrogenik, dimana mempunyai peran sebagai pengganti estrogen yang berfungsi sebagai pemicu perkembangan folikel yang dihasilkan oleh ovarium. Ampas kecap memiliki kendala yaitu tingginya kadar $\mathrm{NaCl}$ sekitar 19,37\%-20,25\%. Keuntungan yang didapat dari ampas kecap yaitu murah harganya dan mudah didapat karena hampir disetiap kota di Indonesia terdapat pabrik kecap. Kelemahan dari ampas kecap yaitu memiliki kandungan garam yang tinggi yaitu sekitar 20,60\%. Kandungan garam yang sangat tinggi dapat diturunkan dengan cara merendam menggunakan asam asetat. Munawati (2001) menyatakan bahwa perendaman ampas kecap dalam larutan asam asetat dapat menurunkan kadar $\mathrm{NaCl}$ menjadi $0,09 \%$ dan peningkatan kadar protein $23,50 \%$. Tujuan dari penelitian ini adalah mengkaji pengaruh penggunaan tepung ampas kecap dengan level 10\%, $12,5 \%$ dan $15 \%$ pada pakan terhadap kualitas interior telur.

\section{MATERI DAN METODE}

Penelitian ini menggunakan 200 ekor ayam petelur strain Lohmann Brown umur 80 minggu dengan bobot awal ratarata $1.932,75 \pm 189,50 \mathrm{~g}$. Ampas kecap diambil di Pabrik Kecap Mirama, Kota Semarang. Bahan pakan yang digunakan terdiri dari jagung kuning, bekatul, bungkil kedelai, tepung ikan, MBM, PMM, lisin, metionin, kapur, premix dan tepung ampas kecap. Kandungan nutrisi pakan disajikan dalam Tabel 1 dan susunan pakan dan kandungan nutrisi pakan percobaan terdapat pada Tabel 2. 
Tabel 1. Kandungan nutrisi bahan pakan

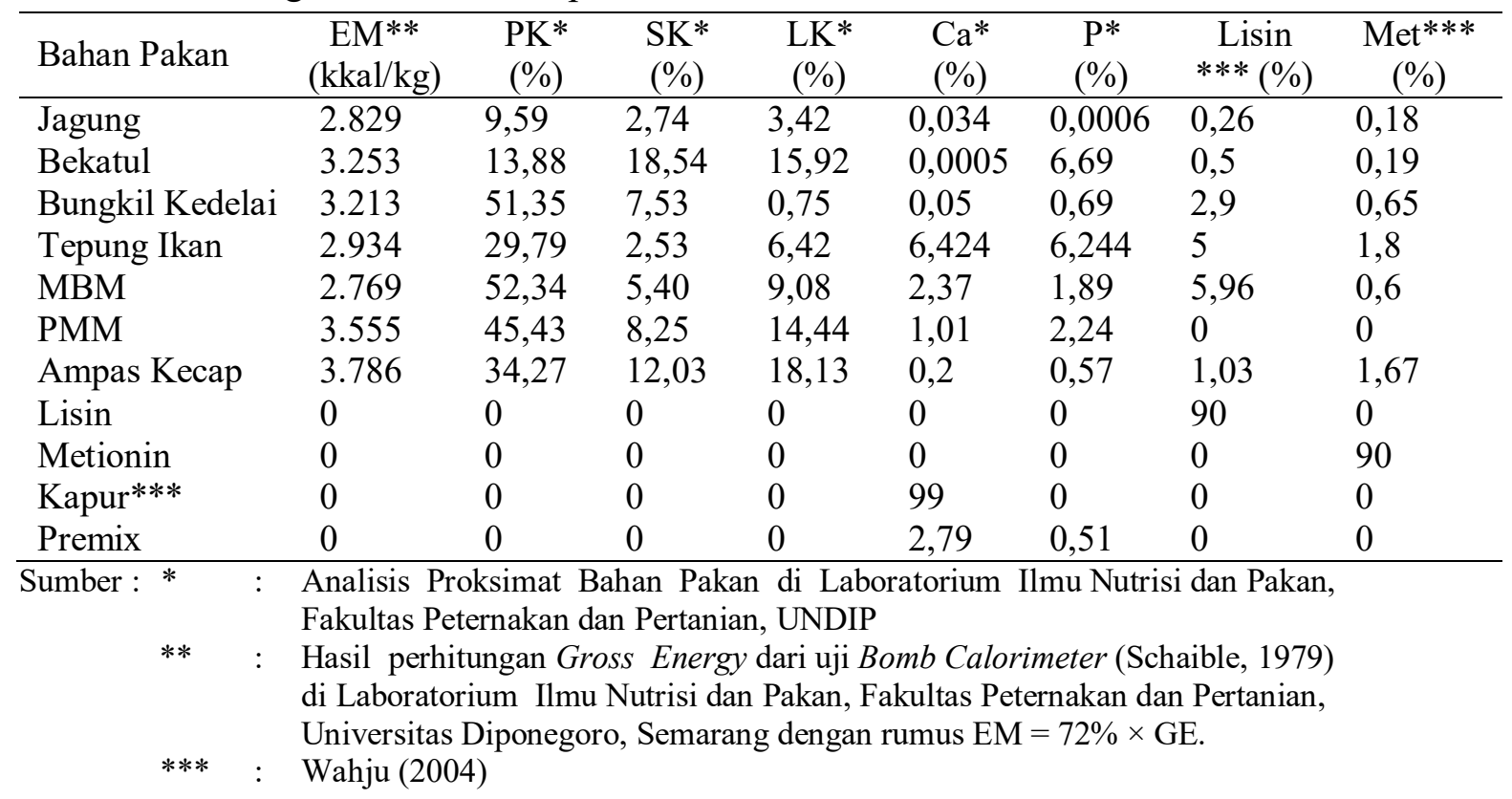

Tabel 2. Susunan pakan dan kandungan nutrisi pakan percobaan

\begin{tabular}{lrrrr}
\hline \multirow{2}{*}{ Bahan Pakan } & \multicolumn{4}{c}{ Perlakuan } \\
\cline { 2 - 5 } & T0 & T1 & T2 & T3 \\
\hline Jagung & 55,00 & 55,00 & 55,00 & 55,00 \\
Bekatul & 15,00 & 11,30 & 10,30 & 9,30 \\
Bungkil Kedelai & 15,50 & 12,00 & 10,50 & 9,00 \\
Tepung Ikan & 4,00 & 2,00 & 2,00 & 2,00 \\
MBM & 2,00 & 2,00 & 2,00 & 2,00 \\
PMM & 2,80 & 2,00 & 2,00 & 2,00 \\
Ampas Kecap & 0,00 & 10,00 & 12,50 & 15,00 \\
Lysin & 0,10 & 0,10 & 0,10 & 0,10 \\
Methionin & 0,10 & 0,10 & 0,10 & 0,10 \\
Kapur** & 4,50 & 4,50 & 4,50 & 4,50 \\
Premix & 1,00 & 1,00 & 1,00 & 1,00 \\
\hline Total & 100,00 & 100,00 & 100,00 & 100,00 \\
\hline EM (kkal/kg) & $2.814,20$ & $2.872,86$ & $2.886,79$ & $2.900,71$ \\
PK (\%) & 18,83 & 18,98 & 18,93 & 18,88 \\
SK (\%) & 5,90 & 6,03 & 6,03 & 6,04 \\
LK (\%) & 5,23 & 6,18 & 6,46 & 6,75 \\
Ca (\%) & 3,99 & 3,87 & 3,87 & 3,88 \\
P (\%) & 1,47 & 1,11 & 1,05 & 0,98 \\
Lisin (\%) & 1,08 & 0,96 & 0,94 & 0,91 \\
Metionin (\%) & 0,40 & 0,50 & 0,53 & 0,56 \\
\hline
\end{tabular}

Rancangan penelitian adalah rancangan acak lengkap (RAL) dengan 4 perlakuan dan 5 ulangan, dan setiap unit percobaan terdiri dari 10 ekor ayam.
Parameter yang teliti adalah skor warna kuning telur, bobot kuning telur dan indeks kuning telur. Pengambilan data dilakukan dengan pengambilan 2 butir sampel telur 
setiap minggu pada setiap unit percobaan dengan total 40 butir telur. Analisis kualitas interior telur dilakukan di Laboratorium Produksi Ternak Unggas, Fakultas Peternakan dan Pertanian, Universitas Diponegoro, Semarang menggunakan alat sebagai berikut kaca datar, yolk color fan, deep micrometer, jangka sorong dan timbangan digital. Data diolah dengan menggunakan analisis ragam (ANOVA).

\section{HASIL DAN PEMBAHASAN}

Pengaruh perlakuan terhadap warna kuning telur, bobot kuning telur dan indeks kuning telur ditampilkan pada Tabel 3.

Tabel. 3. Pengaruh perlakuan terhadap warna, bobot dan indeks kuning telur

\begin{tabular}{lrrrr}
\hline \multicolumn{1}{c}{ Parameter } & \multicolumn{4}{c}{ Perlakuan } \\
\cline { 2 - 5 } & 7,88 & T1 & T2 & T3 \\
\cline { 2 - 5 } & Warna kuning telur & 7,13 & 7,40 & 7,30 \\
Bobot kuning telur (g) & 16,90 & 16,68 & 16,58 & 17,00 \\
Indeks kuning telur & 4,23 & 4,14 & 4,32 & 4,30 \\
IOFC (Rp.) & $8.936,06$ & $42.066,08$ & $54.49944,75$ & $92.9956,89$ \\
\hline
\end{tabular}

\section{Warna Kuning Telur}

Tabel 3 menunjukkan bahwa warna kuning telur pada ayam petelur berumur 80 minggu setelah diberikan perlakuan tepung ampas kecap selama 8 minggu. Hasil analisa menunjukkan bahwa penggunaan tepung ampas kecap tidak memberikan pengaruh nyata terhadap warna kuning telur.

Berdasarkan hasil penelitian pada Tabel 3 didapatkan nilai rerata nilai warna kuning telur dari yang tertinggi hingga terendah yaitu perlakuan T0 7,88; T2 7,40; T3 7,30 dan T1 7,13. Data pada Tabel 3 menunjukkan bahwa perlakuan tidak berpengaruh nyata $(\mathrm{P}>0,05)$ terhadap warna kuning telur. Warna kuning telur hasil penelitian berada pada nilai 7 dimana nilai tersebut tidak sesuai dengan standart yang telah banyak diminati oleh masyarakat. Hal tersebut sesuai dengan pendapat Dennet (1993) yang menyatakan bahwa warna kuning telur yang banyak diminati oleh masyarakat yaitu antara 9-11 dalam skala Roche.

Warna kuning telur yang jauh dari nilai standart diduga dipengaruhi oleh kurangnya kandungan xantofil dalam pakan. Tepung ampas kecap dalam pakan tidak mengandung xantofil, sehingga warna kuning yang dihasilkan oleh kuning telur dapat diperoleh dari bahan pakan lainnya yaitu jagung kuning. Warna kuning telur diperoleh dari pakan berupa jagung kuning, bungkil kedelai, rumput laut dan tepung ikan. Hal ini sesuai dengan pendapat Sikder et al., (1998) yang menyatakan bahwa warna kuning telur dihasilkan oleh pigmen xantofil dan pigmen tersebut diperoleh dari pakan yang dikonsumsi ternak, seperti jagung kuning yang merupakan sumber energi dan penyuplai pigmen. Oleh karena itu, dengan pemberian tepung ampas kecap yang tidak memiliki kandungan pigmen xantofil akan mempengaruhi warna kuning 
telur yang dihasilkan sehingga warna kuning telur menjadi pucat.

\section{Indeks Kuning Telur}

Tabel 3 menunjukkan bahwa indeks kuning telur pada ayam petelur berumur 80 minggu setelah diberikan perlakuan tepung ampas kecap selama 8 minggu. Hasil analisa menunjukkan bahwa penggunaan tepung ampas kecap tidak memberikan pengaruh nyata terhadap indeks kuning telur.

Berdasarkan hasil penelitian pada Tabel 3 di dapatkan nilai rerata nilai indeks kuning telur dari yang tertinggi hingga terendah yaitu perlakuan T2 4,32; T3 4,30; T0 4,24 dan T1 4,14. Data pada Tabel 3 menunjukkan bahwa perlakuan tidak berpengaruh nyata $(\mathrm{P}>0,05)$ terhadap indeks kuning telur. Penurunan nilai indeks kuning telur yang terjadi, dapat diduga karena umur ayam yang digunakan dalam penelitian sudah tua. Namun nilai indeks kuning telur yang diteliti masih dalam batas standart yaitu 0,41-0,43. Hal ini sesuai dengan pendapat Badan Standart Nasioal (2008) yang menyatakan bahwa nilai indeks kuning telur berkisar antara 0,33-0,52.

Indeks kuning telur bergantung pada besar kuning telur. Data bobot total telur yang dihasilkan pada penelitian ini tidak berbeda nyata, sehingga memungkinkan kuning telur yang dihasilkan sama pula baik tinggi maupun kuningnya. Hal tersebut dapat dikarenakan oleh konsumsi protein dalam pakan yang sama, yang berbeda hanyalah komposisi penggunaan tepung ampas kecap. Protein merupakan unsur pokok zat padat yang menghasilkan kuning telur yang sama, sehingga dengan konsumsi yang sama akan menghasilkan kuning telur yang relatif sama pula. Hal ini sesuai dengan pendapat Isroli et al., (2010) yang menyatakan bahwa indeks kuning telur relatif sama walupun skor warna kuning meningkat. Ada beberapa faktor yang mempengaruhi indeks kuning telur diantaranya yaitu waktu pengukuran dan umur telur. Hal ini sesuai dengan pendapat Isroli et al., (2010) yang menyatakan bahwa indeks kuning telur dipengaruhi oleh waktu pengukuran.

Selain protein yang tinggi dalam ampas kecap, kandungan isoflavon juga dapat mempengaruhi. Isoflavon merupakan senyawa aditif yang mempunyai fungsi sebagai fitoestrogen sehingga dapat membantu perkembangan folikel dalam pembentukan kuning telur. Hal ini sesuai dengan pendapat Malik et al. (2015) yang menyatakan bahwa tepung ampas kecap mengandung isoflavon yang dapat meningkatkan kualitas telur dalam pembentukan kuning telur. Tepung ampas kecap juga mampu meningkatkan produktivitas, kualitas telur berupa presentase kuning telur. Umur telur juga mempengaruhi indeks kuning telur, telur yang baru memiliki indeks kuning telur yang tinggi. Hal ini sesuai dengan pendapat Asih (2004) yang menyatakan bahwa semakin bertambahnya umur telur maka indeks kuning telur akan menurun juga dikarenakan adanya penambahan ukuran kuning telur akibat dari perpindahan air dari putih telur ke kuning telur. 


\section{Bobot Kuning Telur}

Tabel 3 menunjukkan bahwa bobot kuning telur pada ayam petelur berumur 80 minggu setelah diberikan perlakuan tepung ampas kecap selama 8 minggu. Hasil analisa menunjukkan bahwa penggunaan tepung ampas kecap tidak memberikan pengaruh nyata terhadap bobot kuning telur.

Berdasarkan hasil penelitian pada Tabel 3 didapatkan nilai rerata nilai indeks kuning telur dari yang tertinggi hingga terendah yaitu perlakuan T3 17,00; T0 16,90; T1 16,68 dan T2 16,58. Data pada Tabel 3 menunjukkan bahwa perlakuan tidak berpengaruh nyata $(\mathrm{P}>0,05)$ terhadap indeks kuning telur. Hasil penelitian menunjukkan bahwa meningkatnya penggunaan tepung ampas kecap sampai taraf $12,5 \%$ cenderung menurunkan bobot kuning telur dari 16,90 (T0) gram menjadi 16,58 gram (T2), tetapi bobot kuning telur kembali meningkat pada T3 atau dengan penggunaan tepung ampas kecap taraf $15 \%$.

Kandungan protein dan lemak yang ada pada tepung ampas kecap diperkirakan memiliki kecernaan protein yang sama dengan bahan pakan yang lain. Peningkatan tepung ampas kecap tidak dapat meningkatkan bobot kuning telur ayam petelur umur 80 minggu. Kuning telur merupakan bagian paling penting dalam telur. Kuning telur mengandung protein lebih tinggi dibandingkan dengan putih telur. Hal ini sesuai dengan pendapat Sudaryani (2006) yang menyatakan bahwa tinggi rendahnya bobot kuning telur yang dihasilkan tergantung dengan ransum yang diberikan, konsumsi ransum dan tingkat kecernaan terhadap ransum juga mempengaruhi terutama kandungan protein. Konsumsi ransum dan tingkat kecernaan sangat mempengaruhi bobot kuning telur yang dihasilkan oleh ayam petelur. Hal ini sesuai dengan pendapat Yuwanta (2010) yang menyatakan bahwa faktor yang mempengaruhi bobot kuning telur yaitu umur ternak, nutrisi dalam pakan, berat telur yang dihasilkan, konsumsi ransum dan tingkat kecernaan terhadap protein.

\section{Income Over Feed Cost (IOFC)}

Penggunaan ampas kecap dapat meningkatkan total pendapatan dan menurunkan biaya pakan, sehingga meningkatkan keuntungan. Perhitungan IOFC untuk T0, T1, T2 dan T3 masingmasing adalah 8.936,06; 42.066,08; 54.4944,75; 92.9956,89. Perlakuan T3 mempunyai nilai tertinggi sedangkan T0 mempunyai nilai terendah. Menurut Siregar (2002), Income Over Feed Cost (IOFC) merupakan selisih dari total pendapatan dengan biaya pakan yang digunakan selama pemeliharaan. Kenaikan nilai Income Over Feed Cost (IOFC) tersebut dapat mengurangi total biaya pakan yang dikeluarkan karena ampas kecap merupakan limbah yang memiliki nilai ekonomis tinggi dan masih memiliki nutrisi yang cukup baik untuk ayam petelur. Solikin (2016) menyatakan bahwa tinggi rendahnya nilai IOFC dikarenakan adanya selisih yang semakin besar atau kecil pada penjualan dengan biaya pakan yang dikeluarkan selama pemeliharaan. 


\section{KESIMPULAN}

Tepung ampas kecap belum mampu memperbaiki kualitas interior telur (warna, indeks dan bobot kuning telur), namun menaikan pendapatan ayam petelur tua. Limbah ampas kecap yang sudah berbentuk tepung dapat dijadikan bahan pakan alternatif.

\section{DAFTAR PUSTAKA}

Badan Standarisasi Nasional. 2008. Telur Ayam Konsumsi. Jakarta.

Dennet, A. B. 1993. Phsiology and Biochemistry of The Domestic Fowl. Vol. 3, Academic Press, London.

Herdiana, R.M., Y. Marchal., R. Dewanti dan Sudiyono. 2014. Pengaruh penggunaan ampas kecap terhadap pertambahan bobot badan harian, konversi pakan, rasio efisiensi protein dan produksi karkas itik lokal jantan umur delapan minggu. Buletin Peternakan. 38 (3): 157-162.

Malik, A., E. Suprijatna, V.D. Yunianto dan L. Djauhari. 2015. Pengaruh isoflavon ampas kecap terhadap antioksidan dan rasio kholesterol LDL/HDL darah ayam petelur. Seminar Nasional. Hasil - Hasil Penelitian dan Pengabdian LPPM. Hal. 252-258.

Sikder, A. C., S. D. Chowdhury, M. K. Rasyhid, A. K. Sarker dan S.C. Das.
1998. Use of dried carrot (DCM) in laying hendiet for egg yolk pigmentation. Asian -Aus. J. Anim. Sci. 11 (3) : 239 -244.

Siregar, E. 2002. Pengaruh Pemberian Tepung Buah Tanjung (Mimusops elengi $L$ ) dalam Ransum terhadap Performans Kelinci Lokal Umur 8-16 minggu. Jurusan Peternakan, Fakultas Pertanian, Universitas Sumatera Utara. Medan.

Sudaryani, T. 2006. Kualitas Telur. Penebar Swadaya, Jakarta.

Solikin, T. 2016. Bobot Akhir, Bobot Karkas dan Income Over Feed and Chick Cost Ayam Sentul Barokah Abadi Farm Ciamis. Fakultas Peternakan, Universitas Padjajaran, Bandung. (Skripsi)

Sukarini, N. E., L.D. Mahfudz dan A.M. Legowo. 2004. Studi penggunaan ampas kecap yang diproses dengan larutan asam asetat untuk pakan terhadap komposisi kimia dan karakteristik fisik daging ayam broiler. J. Ind. Anim. Agri. 29 (3) : $129-135$.

Wahju. 2004. Ilmu Nutrisi Unggas. Cetakan ke - V, Gadjah Mada University Press, Yogyakarta.

Yuwanta, T. 2010. Dasar Ternak Unggas. Gadjah Mada University Press, Yogyakarta 